Reprod. Nutr. Dévelop., 1986, 26 (2 B), 597-603.

\title{
Regulation of metabolism during lactation in the rat
}

\author{
D. H. WILLIAMSON
}

Metabolic Research Laboratory, Nuffield Department of clinical Medicine, Radcliffe Infirmary, Woodstock Road, Oxford OX2 6HE, U.K.

Summary. The physiological, endocrine and biochemical alterations which occur in the lactating rat to allow direction of the nutrients (glucose, amino acids, non-esterified fatty acids, triacylglycerols) to the lactating gland are described. In addition, the short-term changes in the rate of synthesis of milk constituents and the mechanisms whereby they occur are discussed.

\section{Introduction.}

During the period of lactation ( 21 days) in the rat the weight of the average litter (10 pups) increases by an amount approximately equal to the maternal body weight. As rat pups only start to consume solid food in the last few days of lactation this implies that the increase in growth must have been sustained by the mother's milk. All the lactose and protein and a high proportion of the lipid contained in rat milk are synthesized within the lactating mammary gland. Consequently, during lactation the gland has a high requirement for circulating substrates (glucose, amino acids, non-esterified fatty acids and triacylglycerols). The aim of this contribution is to briefly review the physiological, endocrine and biochemical changes which occur in lactation to allow effective milk production to proceed and to outline the short-term regulation of this process. The changes occur in the three distinct phases : (a) prior to parturition; (b) post-partum; (c) on weaning when the gland involutes and lactation ceases. It is intended only to deal with the post-partum alterations and the short-term regulation of metabolism during peak lactation (10-14 days). For a more detailed description of various aspects of this topic and information on other species, the reader should refer to recent reviews (Bauman and Currie, 1980 ; Williamson, 1980 ; Vernon and Flint, 1983 ; Collier et al., 1984).

\section{Physiological changes.}

A striking feature of lactation in the rat is the considerable increase (up to $300 \%$ ) in food intake (Fell, Smith and Campbell, 1963; Ota and Yokohama, $1967)$ and this is accompanied by hypertrophy of the intestinal tract $(100 \%$ 
increase ; Craft, 1970 ; Cripps and Williams, 1975) to allow more rapid absorption of the nutrients. There is also hypertrophy of the mammary gland (about $400 \%$ increase), liver (about 40-50 \%) and heart. Despite the hyperphagia of lactation there is little or no increase in the adipose tissue mass even when the rats are fed a high-fat diet (Sterngrimsdottir, Greenwood and Brasel, 1980). To direct the available substrates and hormones to the mammary gland the blood flow is increased by increasing the proportion of the cardiac output received by the gland (Hanwell and Linzell, 1973). Smaller increases in blood flow occur to liver and intestine of lactating rats.

\section{Endocrine changes.}

The numerous alterations in the metabolism of the tissues of the lactating rat (Table 1) are mainly brought about by changes in the concentration of circulating hormones. Prior to parturition a number of hormones (insulin, steroids, prolactin) play a role in preparing the gland for lactation. Recently, epidermal growth factor

\section{TABLE 1}

Summary of metabolic changes during lactation in the rat.

\begin{tabular}{|c|c|c|}
\hline Tissue & Process & Change \\
\hline Mammary giand & $\begin{array}{l}\text { Glucose utilization } \\
\text { Lactose synthesis } \\
\text { Lipogenesis } \\
\text { Fatty acid esterification } \\
\text { Triacylglycerol uptake } \\
\text { Amino acid utilization } \\
\text { Protein synthesis }\end{array}$ & $\begin{array}{l}\text { Increased } \\
\text { Increased } \\
\text { Increased } \\
\text { Increased } \\
\text { Increased } \\
\text { Increased } \\
\text { Increased }\end{array}$ \\
\hline Liver & $\begin{array}{l}\text { Glucose utilization (glycolysis) } \\
\text { Lipogenesis } \\
\text { Fatty acid esterification } \\
\text { Ketogenesis } \\
\text { Triacylglycerol secretion } \\
\text { Amino acid metabolism } \\
\text { Protein synthesis }\end{array}$ & $\begin{array}{l}\text { Increased } \\
\text { Increased } \\
\text { Increased } \\
\text { Decreased } \\
\text { Decreased } \\
? \\
\text { Unchanged }\end{array}$ \\
\hline $\begin{array}{l}\text { White adipose } \\
\text { tissue }\end{array}$ & $\begin{array}{l}\text { Glucose utilization } \\
\text { Lipogenesis } \\
\text { Triacylglycerol uptake } \\
\text { Lipolysis }\end{array}$ & $\begin{array}{l}\text { Decreased } \\
\text { Decreased } \\
\text { Decreased } \\
\text { Increased }\end{array}$ \\
\hline $\begin{array}{l}\text { Brown adipose } \\
\text { tissue }\end{array}$ & $\begin{array}{l}\text { Glucose utilization } \\
\text { Lipogenesis } \\
\text { Thermogenesis } \\
\text { Triacylglycerol uptake }\end{array}$ & $\begin{array}{l}\text { Decreased } \\
\text { Decreased } \\
\text { Decreased } \\
\text { Decreased }\end{array}$ \\
\hline Intestine & $\begin{array}{l}\text { Glucose utilization } \\
\text { Lipogenesis } \\
\text { Fatty acid esterification } \\
\text { Amino acid metabolism }\end{array}$ & $\begin{array}{l}? \\
\text { Increased } \\
? \\
?\end{array}$ \\
\hline
\end{tabular}

? Indicates where information is not available. 
has also been implicated in the development of mouse mammary gland in vivo (Okamoto and Oka, 1984). Post-partum, the regulation of metabolism in the lactating rat and, in particular, milk production, appears to depend on two hormones, prolactin and insulin. Secretion of prolactin from the pituitary is controlled by the suckling stimulus whereas the blood glucose is mainly responsible for regulation of insulin secretion from the pancreas. The apparent paradox in lactation is that despite the hyperphagia the plasma insulin is lower than in a non-lactating rat (Robinson, Girard and Williamson, 1978; Flint et al., 1979 ; Marynissen, Aerts and Van Assche, 1983). Furthermore, the insulin/glucagon ratio is decreased in lactation (Robinson, Girard and Williamson, 1978). The lower plasma insulin is probably the result of a combination of a lower blood glucose (Robinson, Girard and Williamson, 1978), a decreased $\beta$-cell mass (Marynissen, Aerts and Van Assche, 1983) and increased removal of the hormone by the mammary tissue (Jones, Ilic and Williamson, 1984). The increase in insulin receptor numbers, and in particular those with high affinity for the hormone, on lactating mammary gland (mouse ; Inagaki and Kohmoto, 1982) would support the view that this tissue is an important site of insulin removal. In contrast, the number of insulin receptors does not change on adipocytes (Flint et al., 1979) or hepatocytes (Flint, 1980). In view of the decreased insulin/glucagon ratio in lactation it is of interest that mammary tissue lacks glucagon receptors (Robson, Clegg and Zammit, 1984) and therefore glucagon is unable to affect mammary gland metabolism. It must be emphasized that in addition to the concentration of circulating hormones and the number and affinity of tissue receptors, the rate of delivery is a key factor in hormone action. The influence of local vascularity on hormone receptors in rat mammary gland has been demonstrated by Moore and Forsyth (1980).

\section{Changes in inter-tissue metabolite fluxes.}

The main aim of the changes in tissue metabolism in the lactating rat (Table 1 ) is to preserve the increased intake of nutrients from the diet for milk production in the mammary gland. All tissues of the body receive the prevailing mixture of available substrates via the circulation and therefore the only means to ensure that a particular tissue receives a high proportion of the substrates is to increase their delivery (blood flow) to and utilization by the tissue and to decrease the utilization of the substrates by competing tissues. The main biochemical mechanism whereby such changes in substrate flux can be achieved is by modulation of the rate of transport to the cell or by alteration of the concentration of key enzymes involved in the utilization of the blood-borne substrates.

Triacy/g/ycerols. - In hyperphagic states, the main tissues responsible for removal of the excess nutrients (glucose, triacylglycerols), are white adipose tissue (for storage as triacylglycerols) or brown adipose tissue (for dietary thermogenesis ; Rothwell and Stock, 1979). Thus in the non-lactating rat, dietary fat, present in the circulation as chylomicrons, is taken up by brown and white adipose tissue after hydrolysis to non-esterified fatty acids by lipoprotein lipase and subsequent re-esterification within the tissue. The activity of lipoprotein lipase decreases rapidly in white adipose tissue at parturition and remains low throughout lac- 
tation (Hamosh et al., 1970). Similarly, there is decreased (90\%) uptake of oral triacylglycerols by brown adipose tissue in lactation (C. do Nascimento and D. $H$. Williamson, unpublished results). In contrast, there is a considerable increase in lipoprotein lipase activity in the lactating mammary gland (Hamosh et al., 1970). The net result of these reciprocal changes in the activity of this enzyme is that available plasma triacylglycerols (chylomicrons or VLDL) will be "directed " to the lactating gland.

Glucose. - The main fate of glucose carbon in adipose tissue is conversion to acetyl-CoA and subsequent synthesis of fatty acids. In lactation the process of lipogenesis is greatly depressed in white and brown adipose tissue, whereas the mammary gland is the most important site of lipogenesis when rats are fed a high carbohydrate diet (Robinson, Girard and Williamson, 1978). Again, this direction of glucose to the gland is mainly due to changes in the relative concentrations of key enzymes and, in particular hexokinase (the initiating enzyme for glucose utilization) in adipose and mammary tissues. Glucose is, of course, also required in the lactating gland for lactose synthesis.

Non-esterified fatty acids. - The biochemical changes in white adipose tissue during lactation mean that despite the hyperphagia the tissue is in a net lipolytic state and the fat accumulated during pregnancy is mobilized for production of milk lipid (Naismith, Richardson and Pritchard, 1982). The non-esterified fatty acids released from adipose tissue are either utilized directly by the lactating gland or are re-esterified in the liver and are then secreted as VLDL for subsequent removal by the gland. In lactation the liver appears to be involved in the conservation of lipid by esterifying a higher proportion of long-chain fatty acids it removes from the circulation and converting less to ketone bodies (Whitelaw and Williamson, 1977). Livers of lactating rats also have higher rates of lipogenesis and this may assist in the supply of lipid to the lactating gland in the immediate post-absorptive state.

Amino acids. - The lactating gland has a high requirement for amino acids for synthesis of milk proteins and presumably these are supplied by the increased dietary intake. At present there is no evidence for a "sparing " of amino acid metabolism in other tissues to satisfy the needs of the mammary tissue. It would appear that on a balanced diet amino acids in excess of requirements for protein synthesis will be metabolized by the liver or mammary gland.

Signals. - The integrated changes in the metabolism of the tissues of the lactating rat discussed above are considered to be mainly due to the effects of the high plasma prolactin ; however, the low plasma insulin and the decreased insulin/glucagon ratio are likely to also play a role. It is of interest that so far no hormones have been shown to exert antagonistic effects to those of insulin and prolactin in rat mammary gland.

\section{Short-term regulation of mammary gland metabolism.}

The key to understanding the need for short-term regulation of mammary gland metabolism is that glucose is the precursor for a large proportion of milk fat (lipogenesis) and for the synthesis of lactose so that when its availability decrea- 
ses (e.g. in starvation or on a low carbohydrate-high fat diet) the gland's requirement for this substrate must be decreased, otherwise hypoglycaemia might result because of the depletion of the animal's carbohydrate reserves. Thus in shortterm starvation or after an oral load of fat the rate of lipogenesis and lactose synthesis in the gland decreases and these effects are readily reversed on refeeding carbohydrate (Table 2) (Williamson, Munday and Jones, 1984 ; Bussmann, Ward and Kuhn, 1984). Changes in the same direction occur in protein synthesis in mammary gland (E. da Cruz and D. H. Williamson, unpublished results) and these will prevent the drain on plasma amino acids during starvation (Vina et al., 1983). The most likely signal for initiation of these changes in the rate of synthesis of the macronutrients of the milk are alterations in the plasma insulin, because short-term insulin deficiency decreases lipogenesis and protein synthesis in the gland (Table 1). Another putative signal is the concentration of blood ketone bodies (Williamson, 1980) which can inhibit glucose utilization by mammary tissue in vivo and in vitro (Robinson and Williamson, 1980) and decrease amino acid extraction (Viña et al., 1983). The main effects of changes in plasma prolactin appear to be exerted on protein synthesis in the gland (Table 2). Apart from chan-

\section{TABLE 2}

Summary of changes in metabolic processes in the lactating mammary gland in vivo in response to short-term alterations in diet or hormonal balance.

\section{Situation}

Metabolic process

\section{Starvation $(6 \mathrm{~h})$}

Starvation (24 h)

Starvation (24 h)-refed $(2 \mathrm{~h})$

Triacylglycerol load $(2 \mathrm{~h})$

Insulin deficiency $(2 \mathrm{~h})$

Prolactin deficiency $(24 \mathrm{~h})$

Lipogenesis

Protein synthesis

\begin{tabular}{cc} 
Decreased & Decreased \\
Decreased & Decreased \\
Increased & Increased \\
Decreased & $?$ \\
Decreased & Decreased \\
No change & Decreased \\
\hline
\end{tabular}

? Indicates where information is not available.

ges in concentration of these regulatory signals, other factors play a role in altering the rate of mammary gland metabolism. For example, blood flow to the gland decreases in starvation (Jones and Williamson, 1984) and this will affect both substrate and hormone supply. Recently, the "switch-on " of lipogenesis in the gland on refeeding after a period of starvation has been shown to depend on continued glucose synthesis in the liver (Williamson, llic and Jones, 1985). Thus the short-term regulation of mammary gland metabolism and hence its requirement for nutrients from the circulation is the result of complex interactions between physiological and endocrine factors. A detailed description of the sites of regulation is outside the scope of this contribution but they include transport of metabolites into the secretory cells and changes in activities of the regulatory enzymes of the biosynthetic pathways. 
Acknowledgements. - Mrs. M. Barber is thanked for secretarial assistance. The author is a member of the External Scientific Staff of the Medical Research Council (U. K.).

\section{Résumé. Régulation du métabolisme durant la lactation chez le rat.}

Le présent article décrit les modifications physiologiques, endocrines et biochimiques qui, chez la ratte allaitante, permettent de diriger vers la glande mammaire les différents nutriements (glucose, acides aminés, acides gras non estérifiés, triglycérides). De plus, les changements à court terme dans la vitesse de synthèse des constituants du lait et les mécanismes par lesquels ils se produisent, sont discutés.

\section{References}

BAUMAN D. E., CURRIE W. B., 1980. Partitioning of nutrients during pregnancy and lactation : A review of mechanisms involving homeostasis and homeorhesis. J. Dairy Sci., 63, 1514-1529.

BUSSMANN L. E., WARD S., KUHN N. J., 1984. Lactose and fatty acid synthesis in lactating-rat mammary gland. Effects of starvation, re-feeding and administration of insulin, adrenaline, streptozotocin and 2-bromo- $\alpha$-ergocryptine. Biochem. J., 219, 173-180.

COLLIER R. J., MCNAMARA J. P., WALLACE C. R., DËHOFF M. H., 1984. A review of endocrine regulation of metabolism during lactation. J. anim. Sci, 59, 498-510.

CRAFT I. L., 1970. The influence of pregnancy and lactation on the morphology and absorptive capacity of the rat small intestine. Clin. Sci, 38, 287-295.

CRIPPS A. W., WILLIAMS V. J., 1975. The effect of pregnancy and lactation on food intake, gastrointestinal anatomy and the absorptive capacity of the small intestine in the albino rat. Brit. J. Nutr., 33, 17-32.

FELL B. F., SMITH K. A., CAMPBELL R. M., 1963. Hypertrophic and hyperplastic changes in the alimentary canal of the lactating rat. J. Path. Bact., 85, 179-188.

FLINT D. J., 1980. Changes in the number of insulin receptors of isolated rat hepatocytes during pregnancy and lactation. Biochim. biophys. Acta, 628, 322-327.

FLINT D. J., SINNET-SMITH P. A., CLEGG R. A., VERNON R. G., 1979. Role of insulin receptors in the changing metabolism of adipose tissue during pregnancy and lactation in the rat. Biochem. J., 182, 421-427.

HAMOSH M., CLARY T. R., CHERNICK S. S., SCOW R. O., 1970. Lipoprotein lipase activity of adipose and mammary tissue and plasma triglyceride in pregnant and lactating rats. Biochim. biophys. Acta, 210, 473-482.

HANWELL A., LINZELL J. L., 1973. The time course of cardiovascular changes in lactation in the rat. J. Physiol., 233, 93-109.

INAGAKI T., KOHMOTO K., 1982. Changes in Scatchard plots for insulin binding to mammary epithelial cells from cycling, pregnant and lactating mice. Endocrinology., 110, 176-182.

JONES R. G., WILLIAMSON D. H., 1984. Alterations in mammary-gland blood flow and glucose metabolism in the lactating rat induced by short-term starvation and refeeding. Biosci. Rep., 4. 421-426.

JONES R. G., ILIC V., WILLIAMSON D. H., 1984. Physiological significance of altered insulin metabolism in the conscious rat during lactation. Biochem. J., 220, 455-460.

MARYNISSEN G., AERTS L., VAN ASSCHE F. A., 1983. The endocrine pancreas during pregnancy and lactation in the rat. J. develop. Physiol., 5, 373-381.

MOORE B. P., FORSYTH I. A., 1980. Influence of local vascularity on hormone receptors in mammary gland. Nature, 284, 77-78.

NAISMITH D. J., RICHARDSON D. P., PRITCHARD A. E., 1982. The utilization of protein and energy during lactation in the rat, with particular regard to the use of fat accumulated in pregnancy. J. Nutr., 48, 433-441.

OKAMOTO S., OKA T., 1984. Evidence for physiological function of epidermal growth factor: pregestational sialoadenectomy of mice decreases milk production and increases offspring mortality during lactation period. Proc. nat. Acad. Sci. USA, 81, 6059-6063. 
OTA K., YOKOHAMA A., 1967. Body weight and food consumption of lactating rats nursing various sizes of litters. J. Endocrinol., 38, 263-268.

ROBINSON A. M., WILLIAMSON D. H., 1980. Physiological roles of ketone bodies as substrates and signals in mammalian tissues. Physiol. Rev., 60, 143-185.

ROBINSON A. M., GIRARD J. R., WILLIAMSON D. H., 1978. Evidence for a role for insulin in the regulation of lipogenesis in lactating rat mammary gland: measurements of lipogenesis in vivo and plasma hormone concentrations in response to starvation and refeeding. Biochem. J., 176, 343-346.

ROBSON N. A., CLEGG R. A., ZAMMIT V. A., 1984. Regulation of peripheral lipogenesis by glucagon. Inability of the hormone to inhibit lipogenesis in rat mammary acini in vitro in the presence or absence of agents which alter its effects on adipocytes. Biochem. J., 217, 743-749.

ROTHWELL N. J., STOCK M. J., 1979. A role for brown adipose tissue in diet-induced thermogenesis. Nature, 281, 31-35.

STEINGRIMSDOTTIR L., GREENWOOD M. R. C., BRASEL J. A., 1980. Effect of pregnancy, lactation and a high-fat diet on adipose tissue in Osborne-Mendel rats. J. Nutr., 110, 600-609.

VERNON R. G., FLINT D. J., 1983. Control of fatty acid synthesis in lactation. Proc. Nutr. Soc., 42. 315-331.

VIÑA J. R., PUERTES J. R., MONTORO J. B., VIÑA J., 1983. Effects of starvation and refeeding on amino acid uptake by mammary gland of the lactating rat. Role of ketone bodies. Biochem. J., 216, 343-347.

WHITELAW E., WILLIAMSON D. H., 1977. Effects of lactation on ketogenesis from oleate or butyrate in rat hepatocytes. Biochem. J., 164, 521-528.

WILLIAMSON D. H., 1980. Integration of metabolism in tissues of the lactating rat. FEBS Lett., 117. Suppl. K93-K105.

WILLIAMSON D. H., ILIC V., JONES R. G., 1985. Evidence that the stimulation of lipogenesis in the mammary glands of starved lactating rats re-fed with a chow diet is dependent on continued hepatic gluconeogenesis during the absorptive period. Effects of a gluconeogenic inhibitor, mercaptopicolinic acid in vivo. Biochem J., 228, 727-733.

WILLIAMSON D. H., MUNDAY M. R., JONES R. G., 1984. Biochemical basis of dietary influences on the synthesis of the macronutrients of rat milk. Fed. Proc., 43, 2443-2447. 